\title{
Morbidity and mortality associated with arterial surgery site infections by resistant microorganisms
}

\author{
Morbimortalidade relacionada às infecções de ferida operatória ocasionadas por \\ micro-organismos resistentes em cirurgias arteriais
}

Eduardo Lichtenfels ${ }^{1,2}$, Pedro Alves D’Azevedo ${ }^{3}$, Airton Delduque Frankini, ${ }^{1,2}$, Nilon Erling Jr., ${ }^{1,2}$, Newton Roesch Aerts ${ }^{1,2}$

\begin{abstract}
Background: Surgical site infection is a severe complication of peripheral vascular surgery with high morbidity and mortality rates. Objective: To evaluate the morbidity and mortality of infections of peripheral artery surgery sites caused by resistant microorganisms. Methods: This was a prospective study of a cohort of patients who underwent peripheral artery revascularization procedures and developed surgical site infections between March 2007 and March 2011. Results: Mean age was 63.7 years; males accounted for $64.3 \%$ of all cases. The overall prevalence of bacterial resistance to antimicrobials was $65.7 \%$. The most common microorganism identified was Staphylococcus aureus (30\%). Comparison of the demographic and surgical characteristics of both subsets (resistant versus non-resistant) detected a significant difference in length of preoperative hospital stay ( 9.3 days vs. 3.7 days). The subset of patients with infections by resistant microorganisms had higher rates of reoperation, lower numbers of limb amputations and lower mortality, but the differences compared to the subset without resistant infections were not significant. Long-term survival was similar. Conclusions: This study detected no statistically significant differences in morbidity or mortality between subsets with surgical wound infections caused by resistant and not-resistant microorganisms.
\end{abstract}

Keywords: surgical wound infection; drug resistance; surgery.

\section{Resumo}

Contexto: A infecção de ferida operatória é uma complicação grave da cirurgia vascular periférica e está associada a elevadas taxas de morbidade e mortalidade. Objetivo: Avaliar a morbidade e a mortalidade relacionadas às infecções de ferida operatória causadas por micro-organismos resistentes em cirurgias arteriais periféricas. Métodos: Coorte prospectiva envolvendo pacientes submetidos a procedimentos de revascularização arterial periférica que desenvolveram infecção de sítio cirúrgico, entre março de 2007 e março de 2011. Resultados: A média de idade desses pacientes foi de 63,7 anos; homens representaram 64,3\% de todos os casos. A prevalência total de resistência bacteriana foi de $65,7 \%$. O micro-organismo mais isolado foi o Staphylococcus aureus (30\%). Comparando-se as características demográficas e cirúrgicas das duas amostras (com e sem resistência), foi demonstrado que o tempo de permanência hospitalar apresentou diferença significativa (9,3 dias × 3,7 dias). O grupo de pacientes portadores de infecção por micro-organismo resistente apresentou elevadas taxas de reoperação, amputação de membro inferior e mortalidade, porém sem diferença estatística quando comparado ao grupo sem resistência. No longo prazo, a sobrevida foi similar. Conclusão: este estudo não demonstrou diferença estatística quanto a morbidade e mortalidade entre os grupos com infecção de ferida operatória ocasionada por micro-organismos resistentes e não resistentes.

Palavras-chave: infecção de ferida operatória; resistência medicamentosa; cirurgia.

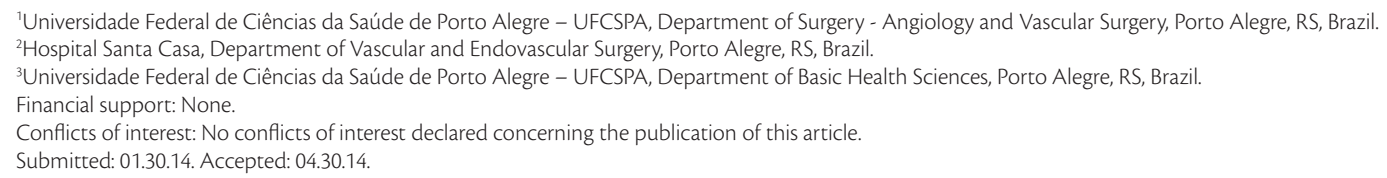

The study was carried out at the Department of Surgery - Angiology and Vascular Surgery, UFCSPA, the Department of Basic Health Sciences, UFCSPA, and the Department of Vascular and Endovascular Surgery, Santa Casa Hospital, Porto Alegre, Brazil. 


\section{INTRODUCTION}

Surgical site infection is a severe complication of peripheral vascular surgery. Surgical site infection occurs in $0.9-22 \%$ of arterial vascular surgeries, and recent series have reported rates of around 3\%. ${ }^{1,2}$ Deep infection with involvement of the wall of the operated artery or the implanted graft occurs in 1.2$13 \%$ of arterial surgeries. ${ }^{2,3}$ França et al. reported a $4.6 \%$ incidence of synthetic graft infection in peripheral vascular surgery. ${ }^{2}$ This type of infection is more frequent in emergency surgeries and inguinal dissections and when vascular grafts are used in the femoral region or via a subcutaneous route. Treatment is complex, involving reoperation, use of wide-spectrum antimicrobials and extended hospital stays, resulting in high mortality (10-76\%) and morbidity rates $(8-53 \%){ }^{2-5}$

The microorganisms most frequently involved in surgical site infections are Staphylococcus aureus and Coagulase-negative Staphylococcus ${ }^{5-7}$ Later infections are often caused by Coagulase-negative Staphylococcus. Gram-negative bacterial infections are very destructive and are often caused by Pseudomonas aeruginosa. ${ }^{8,9}$

The recent occurrence of resistant strains has raised new concerns about antimicrobial prophylaxis and treatment and morbidity and mortality rates. Methicillin-resistant Staphylococcus aureus (MRSA) is currently the most frequently isolated pathogen in complex and severe infections related to vascular surgery. ${ }^{6}$ Prolonged prophylaxis and indiscriminate use of antimicrobials contributed to the development of bacterial resistance. ${ }^{7,10}$ In turn, the increased incidence of multi-resistant pathogens in vascular surgeries contributes to increased morbidity and mortality rates. ${ }^{6,9,11,12}$ However, some authors found that no increase in morbidity ${ }^{13}$ or mortality was associated with MRSA infections. ${ }^{14}$

This study was conducted with the aim of determining the impact of bacterial resistance to antibiotics on morbidity and mortality from surgical site infections after peripheral artery surgery.

\section{METHODS}

This was a cohort study of patients who underwent peripheral artery revascularization surgery from March 2007 to March 2011 and who developed surgical site infections during the postoperative period. Sample selection was consecutive. Demographic data, comorbid conditions, surgical details, microbiology and characteristics of wound infection and hospital stay were reviewed. Presence or absence of bacterial resistance to antibiotics was used to stratify the sample. Data on readmissions and repeat operations during the follow-up period were also recorded. The primary outcome was mortality; secondary outcomes were reoperation, graft excision and lower limb amputation. Patients who were subjected to limb revascularization procedures had critical limb ischemia. This study was approved by the ISCMPA ethics committee.

Bacterioscopic examination, cultures and antimicrobial susceptibility tests were conducted for all cases. The material collected comprised surgical site secretions, tissues or graft fragments (if affected) with clinical diagnoses of infection. All material was collected by the same researcher and analyzed by the same laboratory, following Clinical and Laboratory Standards Institute procedures. ${ }^{15}$ Polymicrobial samples and samples with negative culture results were excluded from the study. Patients with negative cultures were also excluded from the study. All patients in this study received a prophylactic antibiotic prior to skin incision (cephalosporin).

Bacterial resistance to antimicrobials was defined as follows: Staphylococcus aureus - resistance to oxacillin (all beta-lactams), Coagulase-negative Staphylococcus - resistance to oxacillin (all betalactams), Klebsiella pneumoniae, Enterobacter, Escherichia coli and Proteus mirabilis - resistance to amikacin, ceftriaxone, cefepime or ciprofloxacin, Pseudomonas aeruginosa - resistance to imipenem or only sensitivity to imipenem but resistant to other antimicrobials, Enterococcus feacalis - resistance to vancomycin or teicoplanin, and Streptococcus viridans - resistance to penicillin.

Comparisons of the results for quantitative variables were performed using Student's $t$ test and the Mann Whitney test. Categorical variables were compared using chi-square tests and Fisher's exact test. Symmetry of data distribution was evaluated using the Kolmogorov-Smirnov test $(\mathrm{P}<.10)$. For survival analysis, the Kaplan-Meier method was used to identify major factors associated with mortality and then we constructed a Cox multiple regression model (Wald method) with death as the dependent variable. Variables with significant or borderline $(\mathrm{P}<.10)$ differences according to the bivariate analysis were included in this model. Statistical tests with a two-tailed $p$-value $<.05$ were considered significant. Analyses were performed using SPSS 17 (Statistical Package for Social Sciences) from SPSS Inc, Chicago, IL. 


\section{RESULTS}

\section{Baseline characteristics}

During the study period, seven hundred patients were treated at our department using peripheral artery surgery. Twenty patients with polymicrobial and negative cultures were excluded from the study. Data from seventy patients who developed surgical site infection after peripheral artery surgery were analyzed during the study, stratified into two subsets: those infected by resistant bacteria and those infected by non-resistant bacteria. The patients' mean age was 63.7 years, and males predominated $(64.3 \%)$. Patients' demographic data and differences between subsets are summarized in Table 1. No significant differences in demographic characteristics between the two subsets were detected. Mean preoperative hospital stay was significantly longer for patients with infection due to resistant microorganisms ( $\mathrm{P}=0.001)$. No significant differences between groups were detected for the variables use of therapeutic antimicrobials, graft implantation, type of surgery or Szilagyi ${ }^{16}$ classification. The principal surgical characteristics are shown in Table 1.

\section{Microbiology}

The most frequent microorganism isolated from surgical site infections was Staphylococcus aureus, present in $30 \%$ of all cases and the most prevalent bacteria in both subsets. Overall prevalence of bacterial resistance to antimicrobials was $65.7 \%$. Infections due to Coagulase-negative Staphylococcus and Escherichia coli were significantly more common $(\mathrm{P}=0.001)$ in the group with non-resistant bacteria; whereas infection due to Enterobacter was statistically more common $(\mathrm{P}=0.001)$ in the group with resistant bacteria. Table 2 lists all of the microbiological analysis results.

\section{Morbidity and mortality}

The group of patients with resistant surgical site infections exhibited higher rates of repeat surgery,

Table 1. Demographic and surgical characteristics of patients with surgery wound infections.

\begin{tabular}{|c|c|c|c|c|}
\hline Characteristics & $\begin{array}{c}\text { Total } \\
(n=70)\end{array}$ & $\begin{array}{c}\text { Non-resistant } \\
(\mathrm{n}=24)\end{array}$ & $\begin{array}{l}\text { Resistant } \\
(n=46)\end{array}$ & $\mathrm{P}$ \\
\hline Age, years $\pm S D$ & $63.7 \pm 8.8$ & $65.1 \pm 10.7$ & $62.9 \pm 7.6$ & 0.234 \\
\hline Males, n (\%) & $45(64.3)$ & $14(58.3)$ & $31(67.4)$ & 0.626 \\
\hline \multicolumn{5}{|l|}{ Comorbidities, n (\%) } \\
\hline Smoking & $59(84.3)$ & $19(79.2)$ & $40(87.0)$ & 0.493 \\
\hline Hypertension & $50(71.4)$ & $19(79.2)$ & $31(67.4)$ & 0.406 \\
\hline Coronary artery disease & $27(38.6)$ & $8(33.3)$ & $19(41.3)$ & 0.609 \\
\hline Diabetes mellitus & $28(40.0)$ & $10(41.7)$ & $18(39.1)$ & 1.000 \\
\hline Obesity (BMI>30) & $14(20.0)$ & $6(25.0)$ & $8(17.4)$ & 0.534 \\
\hline Therapeutic preop. antibiotics, $\mathrm{n}(\%)$ & $19(27.1)$ & $6(25.0)$ & $13(28.3)$ & 1.000 \\
\hline Preoperative stay, days $\pm S D(M e)$ & $7.4 \pm 8.2(5.0)$ & $3.7 \pm 4.2(2.5)$ & $9.3 \pm 9.1(7.0)$ & 0.001 \\
\hline Type of surgery, n (\%) & & & & 0.114 \\
\hline Femoropopliteal & $29(41.4)$ & $10(41.7)$ & $19(41.3)$ & \\
\hline Aortobifemoral & $16(22.9)$ & $3(12.5)$ & $13(28.3)$ & \\
\hline Distal revascularization & $6(8.6)$ & $2(8.3)$ & $4(8.7)$ & \\
\hline Axilobifemoral & $8(11.4)$ & $4(16.7)$ & $4(8.7)$ & \\
\hline Iliofemoral crossover & $3(4.3)$ & $0(0.0)$ & $3(6.5)$ & \\
\hline Femorofemoral crossover & $4(5.7)$ & $3(12.5)$ & $1(2.2)$ & \\
\hline Iliofemoral & $2(2.9)$ & $2(8.3)$ & $0(0.0)$ & \\
\hline Aortoiliac & $2(2.9)$ & $0(0.0)$ & $2(4.3)$ & \\
\hline Use of graft, n (\%) & $54(77.1)$ & $21(87.5)$ & $33(71.7)$ & 0.234 \\
\hline Topography of infection, $\mathrm{n}(\%)$ & & & & 0.401 \\
\hline Inguinal & $49(70.0)$ & $17(70.8)$ & $32(69.6)$ & \\
\hline Lower limb & $16(22.9)$ & $4(16.7)$ & $12(26.1)$ & \\
\hline Abdomen & $5(7.1)$ & $3(12.5)$ & $2(4.3)$ & \\
\hline Classification of infection, $\mathrm{n}(\%)$ & & & & 0.624 \\
\hline Superficial & $20(28.6)$ & $9(37.5)$ & $11(23.9)$ & \\
\hline Incisional & $36(51.4)$ & $10(41.7)$ & $26(56.5)$ & \\
\hline Incisional with graft exposure & $14(20.0)$ & $5(20.8)$ & $9(19.5)$ & \\
\hline
\end{tabular}

Me: Median, concentration of $50 \%$ of the sample with values less than or equal to the median. 
but lower rates of limb amputation and mortality, although the differences were not significant. These data are summarized in Table 3. Multivariate analysis (logistic regression) of parameters that were statistically significant in bivariate analyses did not detect significant associations with death $(\mathrm{P}>0.05)$.

One-year survival rates for the non-resistant and resistant subsets were $87.9 \%$ and $79.7 \%$ respectively and 5 -year survival rates were $65.9 \%$ and $47.6 \%$ respectively. Analysis of Kaplan-Meier curves did not detect significant differences between the subsets with and without resistant bacteria (Mantel-Cox log rank test $=0.206, \mathrm{P}=0.652$ ). There were therefore no statistically significant differences between mean time of survival estimates for the subsets with antimicrobial resistant ( 42.7 months \pm 3.2 days) and non-resistant (48.7 months \pm 6.6 days) pathogens (Figure 1).

\section{DISCUSSION}

Resistant bacterial strains raise new concerns about antimicrobial prophylaxis and treatment and morbidity and mortality rates within the context of peripheral vascular surgery. ${ }^{17}$ The importance of bacteria that are resistant to antibiotics lies in the fact that they have become much more prevalent in hospitals, ${ }^{18,19}$ reducing the efficacy of antimicrobial treatments, ${ }^{20}$ disseminating resistance,${ }^{21}$ increasing medical costs ${ }^{22}$ and raising morbidity and mortality rates among surgery patients. ${ }^{6,9,11,12}$

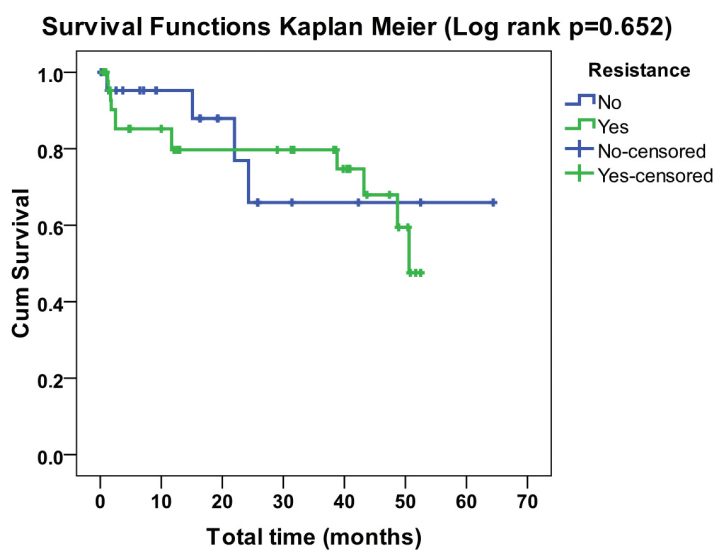

Figure 1. Survival curve (Kaplan-Meier) for patients with resistant infections and non-resistant infections.

Table 2. Distribution of organisms isolated from surgical wound infections in vascular patients.

\begin{tabular}{lccc}
\hline \multicolumn{1}{c}{ Microorganism } & $\begin{array}{c}\text { Total } \\
\mathrm{n}(\%)\end{array}$ & $\begin{array}{c}\text { Non-resistant } \\
\mathrm{n}(\%)\end{array}$ & $\begin{array}{c}\text { Resistant } \\
\mathrm{n}(\%)\end{array}$ \\
\hline Staphylococcus aureus & & & \\
Coagulase-negative Staphylococcus & $21(30)$ & $6(25.0)$ & $15(32.6)$ \\
Klebsiella pneumoniae & $20(28.6)$ & $12(50.0)$ & $8(17.4)$ \\
Enterobacter sp. & $8(11.4)$ & 0 & $8(17.4)$ \\
Pseudomonas aeruginosa & $7(10)$ & 0 & $7(15.2)$ \\
Escherichia coli & $5(7.1)$ & $1(4.2)$ & $4(8.7)$ \\
Proteus mirabilis & $4(5.7)$ & $3(12.5)$ & $1(2.2)$ \\
Streptococcus viridans & $3(4.3)$ & 0 & $3(6.5)$ \\
Enterococcus feacalis & $1(1.4)$ & $1(4.2)$ & 0 \\
TOTAL & $1(1.4)$ & $1(4.2)$ & 0 \\
\hline
\end{tabular}

Table 3. Analysis of primary and secondary outcomes (mortality and morbidity) for patients with resistant and non-resistant bacterial infections.

\begin{tabular}{lcccc}
\hline \multicolumn{1}{c}{ Characteristics } & $\begin{array}{c}\text { Totals } \\
\mathrm{n}(\%)\end{array}$ & $\begin{array}{c}\text { Non-resistant } \\
\mathrm{n}(\%)\end{array}$ & $\begin{array}{c}\text { Resistant } \\
\mathrm{n}(\%)\end{array}$ \\
\hline Reoperation, $\mathrm{n}(\%)$ & $62(88.6)$ & $19(79.2)$ & $43(93.5)$ & 0.164 \\
Lower limb amputation, $\mathrm{n}(\%)$ & $33(47.1)$ & $9(37.5)$ & $24(52.2)$ & 0.360 \\
Excision of graft, $\mathrm{n}(\%)$ & $25(35.7)$ & $12(50.0)$ & $13(28.3)$ & 0.124 \\
Mortality, $\mathrm{n}(\%)$ & $14(20.0)$ & $4(16.7)$ & $10(21.7)$ & 1.000 \\
Overall & $9(64.3)$ & $3(75.0)$ & $6(60.0)$ & \\
Specific (related to infection) & $5(35.7)$ & $1(25.0)$ & $4(40.0)$ & 0.534 \\
Postoperative mortality, $\mathrm{n}(\%)$ & & & & \\
Early & $7(10.0)$ & $1(4.2)$ & $6(13.0)$ & \\
Late & $7(10.0)$ & $3(12.5)$ & $4(8.7)$ & 46 \\
TOTAL & 70 & 24 & \\
\hline
\end{tabular}


The main factors involved in development of surgical site infections are graft implantation, local complications, age, comorbidities, ${ }^{23-28}$ grafts in extra-anatomical positions, prolonged preoperative hospital stays, emergency surgery, extended periods in surgery, concomitant gastrointestinal surgery and arterial reoperation. ${ }^{3,29}$ In this study, patients had a high mean age, were predominantly male and all had comorbidities, most of which were multiple, which are typical characteristics of patients undergoing peripheral artery surgery. Patients who developed infections caused by resistant microorganisms had longer preoperative hospital stays, which the literature shows can be related to increased infection rates and the prevalence of resistant bacteria. ${ }^{30}$ One explanation for this long preoperative stay could be difficulties with availability of hospital beds and the need to conduct extensive investigations before the revascularization procedure. Other baseline characteristics were similar for both subsets in this study.

Staphylococcus aureus, Coagulase-negative Staphylococcus, Pseudomonas, Escherichia coli, Enterobacter and Proteus are commonly isolated from surgical site infections ${ }^{5,6,9}$ Overall, the most common pathogen is Staphylococcus aureus (33-55\%). ${ }^{7}$ Cowie et al. found that MRSA was the second most frequent microorganism $(21 \%)$ isolated from infections in patients submitted to vascular surgery. ${ }^{11}$ The most prevalent microorganism causing infection in our study was Staphylococcus aureus (30\%), followed by Coagulase-negative Staphylococcus (28.6\%). Many authors report that Coagulase-negative Staphylococcus is one of the microorganisms most often responsible for hospital infections ${ }^{14}$ and especially so with relation to surgical site infections after vascular surgery., 5,6,931-36 It is also associated with high rates of antimicrobial resistance. ${ }^{32,34}$ Our data confirmed a high prevalence of Coagulase-negative Staphylococcus $(28.6 \%$ overall), but this pathogen was significantly more prevalent among the non-resistant group (50\% vs. $17.4 \%)$.

Many authors agree that the increased incidence of multi-resistant pathogens and more aggressive strains in vascular surgery infections contributes to high rates of morbidity and mortality, ${ }^{6,9,11,12}$ with mortality rates of up to $75 \%$ reported. ${ }^{6,9}$ High rates of amputation (40\%) and prosthesis excision (11.5\%) and longer duration hospital stays are reported when patients are develop surgical site infections that have resistance. ${ }^{12}$ Cowie et al. showed that
MRSA infections in patients undergoing vascular procedures increased the risk of mortality and clinical complications, including the need for hospitalization in the intensive care unit, repeated hospitalizations and interventions, and longer hospitalization. ${ }^{11}$ A study conducted by Taylor et al. showed that infections caused by Staphylococcus aureus resistant to beta-lactam antibiotics are associated with high morbidity rates, longer hospital stays (29.6 days vs. 22.7 days), higher rates of lower limb amputation $(40 \%)$ and a greater probability that an infected graft will have to be removed (7.7\%). ${ }^{12}$ However, some authors found no increase in morbidity ${ }^{13}$ or mortality associated with MRSA infection. ${ }^{14}$

In our study, patients with resistant surgical wound infections had higher rates of repeat surgeries, and lower limb amputation and mortality; but these results were not statistically significant. On the other hand, the group with non-resistant infections had a high rate of graft excision, which was probably associated with early and aggressive treatment. Multivariate analysis showed that mortality was not associated with bacterial resistance, after adjustment of baseline factors. Patients with non-resistant infections had higher survival rates after one-year and five-year follow-up, but this result also failed to attain significance. Long-term survival was statistically similar for both subsets. This finding could be due to the multiple comorbidities, advanced diseases and high cardiovascular risk levels of these patients. These results shows that vascular surgery patients with resistant surgical site infections may suffer worse outcomes, especially over the short-term follow-up period, irrespective of correct management and care, with high rates of complications and death.

Study limitations include the sample size, lack of uniformity in the infection samples collected, exclusion of cases with polymicrobial infections and with negative cultures, and the sample drawn from a specific and limited population, consisting of patients with multiple advanced diseases who face barriers to access of appropriate medical support. It is probable that statistical analysis of a larger sample could detect more significant results.

This study detected no statistical differences in morbidity or mortality between a subset of patients with surgical wound infections caused by resistant microorganisms and another with non-resistant infections. Patient follow-up revealed a trend towards poorer outcomes among patients with resistant infections, but over the long term survival was similar in both subsets. 


\section{REFERENCES}

1. Frankini $A D$, Cardozo MA, Lichtenfels E. Infecção em Prótese Vascular. In: Brito CJ, editor. Cirurgia Vascular. 2 ed. Rio de Janeiro: Revinter; 2008. p. 866-83.

2. Moreira RCR. Infecção local pós-operatória em cirurgia arterial. Cir Vasc Angiol. 1995;11:46-54.

3. Bandyk DF. Infection in Prosthetic Vascular Grafts. In: Rutherford RB, editor. Vascular Surgery. Philadelphia: Saunders Company; 2000. p. 733-51.

4. França LHG, Stahlke HJ, Garschagen MT, Parchen CFR. Fatores de risco associados à infecção, amputação e mortalidade em pacientes submetidos a pontes arteriais infra-inguinais. Estudo retrospectivo de 27 casos. J Vasc Bras. 2004;3:214-22.

5. Moreira RCR. Infecção em Próteses Vasculares. In: Maffei FHA, editor. Doenças Vasculares Periféricas. 2 ed. Rio de Janeiro: Guanabara-Koogan; 2002. p. 931-42.

6. Naylor AR, Hayes PD, Darke S. A prospective audit of complex wound and graft infections in Great Britain and Ireland: the emergence of MRSA. Eur J Vasc Endovasc Surg. 2001;21(4):28994. http://dx.doi.org/10.1053/ejvs.2001.1311. PMid:11359327

7. Terpstra S, Noordhoek GT, Voesten HGJ, Hendriks B, Degener JE. Rapid emergence of resistant coagulase-negative staphylococci on the skin after antibiotic prophylaxis. J Hosp Infect. 1999;43(3):195-202. http://dx.doi.org/10.1053/jhin.1999.0636. PMid:10582186

8. Cardozo MA, Frankini AD, Bonamigo TP. Use of superficial femoral vein in the treatment of infected aortoiliofemoral prosthetic grafts. Cardiovasc Surg. 2002;10(4):304-10. http:// dx.doi.org/10.1016/S0967-2109(02)00024-8. PMid:12359398

9. Styers D, Sheehan DJ, Hogan P, Sahm DF. Laboratory-based surveillance of current antimicrobial resistance patterns and trends among Staphylococcus aureus: 2005 status in the United States. Ann Clin Microbiol Antimicrob. 2006;5(1):2-9. http:// dx.doi.org/10.1186/1476-0711-5-2. PMid:16469106

10. Lichtenfels E, Lucas ML, Webster R, D’Azevedo PA. Profilaxia antimicrobiana em cirurgia vascular periférica: cefalosporina ainda é o padrão-ouro? J Vasc Bras. 2007;6(4):378-87. http:// dx.doi.org/10.1590/S1677-54492007000400012.

11. Cowie SE, Ma I, Lee SK, Smith RM, Hsiang YN, Abarca Aguilar F. Nosocomial MRSA infection in vascular surgery patients: impact on patient outcome. Vasc Endovascular Surg. 2005;39(4):327-34. http://dx.doi.org/10.1177/153857440503900404. PMid:16079941

12. Taylor MD, Napolitano LM. Methicillin-resistant Staphylococcus aureus infections in vascular surgery: increasing prevalence. Surg Infect (Larchmt). 2004;5(2):180-7. http://dx.doi.org/10.1089/ sur.2004.5.180. PMid:15353115

13. Cerveira JJ, Lal BK, Padberg FT Jr, Pappas PJ, Hobson RW 2nd. Methicillin-resistant Staphylococcus aureus infection does not adversely affect clinical outcome of lower extremity amputations. Ann Vasc Surg. 2003;17(1):80-5. http://dx.doi. org/10.1007/s10016-001-0341-z. PMid:12522705

14. Menon KV, Whiteley MS, Burden P, Galland RB. Surgical patients with methicillin resistant staphylococcus aureus infection: an analysis of outcome using P-POSSUM. J R Coll Surg Edinb. 1999;44(3):161-3. PMid:10372484.

15. CLINICAL AND LABORATORY STANDARDS INSTITUTE (CLSI). Performance standards for antimicrobial susceptibility testing, sixteenth informational supplement, document M100-S16. Wayne, PA, USA: CLSI; 2006.
16. Szilagyi DE, Smith RF, Elliott JP, Vrandecic MP. Infection in arterial reconstruction with synthetic grafts. Ann Surg. 1972;176(3):32123. http://dx.doi.org/10.1097/00000658-197209000-00008. PMid:4262892

17. Jones RN. Global aspects of antimicrobial resistance among key bacterial pathogensresults from the 1997-2001 SENTRY Antimicrobial Program. Semin Respi Clin Infect Dis. 2001;32:S81-156.

18. National Nosocomial Infections Surveillance System, and the A report from the NNIS System. National Nosocomial Infections Surveilliance (NNIS) System Report, data summary from January 1992 through June 2004, issued October 2004. Am J Infect Control. 2004;32(8):470-85. http://dx.doi.org/10.1016/j. ajic.2004.10.001. PMid:15573054

19. Murray PR, Rosenthal KS, Pfaller MA. Microbiologia Médica. 5 ed. Rio de Janeiro: Elsevier; 2006.

20. Kang $\mathrm{Cl}$, Kim SH, Park WB, et al. Bloodstream infections caused by antibiotic-resistant gram-negative bacilli: risk factors for mortality and impact of inappropriate initial antimicrobial therapy on outcome. Antimicrob Agents Chemother. 2005;49(2):760-6. http://dx.doi.org/10.1128/ AAC.49.2.760-766.2005. PMid:15673761

21. Chambers HF. The changing epidemiology of Staphylococcus aureus? Emerg Infect Dis. 2001;7(2):178-82. http://dx.doi. org/10.3201/eid0702.010204. PMid:11294701

22. McGowan JE Jr. Economic impact of antimicrobial resistance. Emerg Infect Dis. 2001;7(2):286-92. http://dx.doi.org/10.3201/ eid0702.010228. PMid:11294725

23. Cruse PJ, Foord R. The epidemiology of wound infection. A 10year prospective study of 62,939 wounds. Surg Clin North Am. 1980;60(1):27-40. PMid:7361226.

24. Dellinger EP. Infecções cirúrgicas e escolha dos antimicrobianos. In: Townsend CM, editor. Sabiston: Tratado de Cirurgia. 6 ed. Rio de Janeiro: Guanabara Koogan; 2003. p. 182-200.

25. Fry DE. Surgical infections. Boston: Little Brown; 1995.

26. Howard RJ, Simmons RL. Surgical infectious disease. Norwalk: Appleton-Lange; 2008.

27. Linton RR. The prophylactic use of the antibiotics in clean surgery. Surg Gynecol Obstet. 1961;112:218-20. PMid:13762507.

28. Reifsnyder T, Bandyk D, Seabrook G, Kinney E, Towne JB. Wound complications of the in situ saphenous vein bypass technique. J Vasc Surg. 1992;15(5):843-50. http://dx.doi.org/10.1016/07415214(92)90719-O. PMid:15785429.Rubin JR, Malone JM, Goldstone J. The role of the lymphatic system in acute arterial prosthetic graft infections. J Vasc Surg. 1985;2(1):92-8. http:// dx.doi.org/10.1016/0741-5214(85)90178-8. PMid:3880833

30. Levy MF, Schmitt DD, Edmiston CE, et al. Sequential analysis of staphylococcal colonization of body surfaces of patients undergoing vascular surgery. J Clin Microbiol. 1990;28(4):664-9. PMid:2332464.

31. Wengrovitz M, Atnip RG, Gifford RRM, Neumyer MM, Heitjan DF, Thiele BL. Wound complications of autogenous subcutaneous infrainguinal arterial bypass surgery: predisposing factors and management. J Vasc Surg. 1990;11(1):156-63. http:// dx.doi.org/10.1016/0741-5214(90)90340-G. PMid:2296096

32. Bandyk DF, Kinney EV, Riefsnyder TI, Kelly H, Towne JB Treatment of bacteria-biofilm graft infection by in situ replacement in normal and immune-deficient states. J Vasc Surg. 1993;18(3):398-406. http://dx.doi.org/10.1016/07415214(93)90257-M. PMid:8104253 
33. Bergamini TM, Bandyk DF, Govostis D, Vetsch R, Towne JB. Identification of Staphylococcus epidermidis vascular graft infections: a comparison of culture techniques. J Vasc Surg. 1989;9(5):665-70. PMid:2524605.

34. Hicks RC), Greenhalgh RM. The pathogenesis of vascular graft infection. Eur J Vasc Endovasc Surg. 1997;14(Suppl A):5-9. http:// dx.doi.org/10.1016/S1078-5884(97)80143-8. PMid:9467604

35. Moreira RCR. Estudo bacteriológico de linfonodos inguinais de pacientes submetidos à cirurgia arterial. Curitiba: Universidade Federal do Paraná; 1991.

36. Timi JRR. Estudo bacteriológico da placa aterosclerótica da artéria femoral. Curitiba: Universidade Federal do Paraná; 1992.
Correspondence

Eduardo Lichtenfels

Av. Toropi 111/1702

CEP 90470-480 - Porto Alegre (RS), Brazi

E-mail: elichtenfels@gmail.com

Author information

EL - M.D. Associate professor, Department of Surgery - Angiology and Vascular Surgery, Universidade Federal de Ciências da Saúde de Porto Alegre - UFCSPA; Vascular and Endovascular Surgeon, Hospital Santa Casa.

PAD - PhD. Associate professor, Department of Basic Health Sciences, Universidade Federal de Ciências da Saúde de Porto Alegre UFCSPA

ADF - M.D. Associate professor, Department of Surgery - Angiology and Vascular Surgery, Universidade Federal de Ciências da Saúde de Porto Alegre - UFCSPA; Vascular and Endovascular Surgeon, Hospital Santa Casa.

NEJ - M.D. Associate professor, Department of Surgery - Angiology and Vascular Surgery, Universidade Federal de Ciências da Saúde de Porto Alegre - UFCSPA; Vascular and Endovascular Surgeon, Hospital Santa Casa.

NRA - M.D. Associate professor, Department of Surgery - Angiology and Vascular Surgery, Universidade Federal de Ciências da Saúde de

Porto Alegre - UFCSPA; Head of the Department of Vascular and Endovascular Surgery, Hospital Santa Casa.

Author contributions Conception and design: EL, PAD, ADF Analysis and interpretation: EL Data collection: $\mathrm{EL}$ Writing the article: EL, PAD, ADF Critical revision of the article: EL, PAD, AIF, NRA Final approval of the article*: EL, PAD, ADF, NRA Statistical analysis: EL Overall responsibility: EL Obtained funding: None

${ }^{*}$ All authors have read and approved of the final version of the article submitted to I Vasc Bras. 